\title{
Penal Mediation in Preventing Social Conflict
}

\author{
Siswanto $^{1 *}$, A. M. Syukri Akub ${ }^{2}$, Wiwie Heryani ${ }^{3}$ \\ ${ }^{1}$ Graduate Student, Faculty of Law, Hasanuddin University, Indonesia \\ ${ }^{2}$ Professor, Faculty of Law, Hasanuddin University, Indonesia \\ ${ }^{3}$ Associate Professor, Faculty of Law, Hasanuddin University, Indonesia
}

DOI: $10.36348 /$ sijlcj.2020.v03i04.002 $\quad$ | Received: 26.03 .2020 | Accepted: 02.04.2020 | Published: 07.04 .2020

*Corresponding author: Siswanto

\section{Abstract}

The purpose of this study is to analyze the penal mediation that does not aim to achieve formal justice and the practice of penal mediation at the Manokwari Police Department. The research method is normative legal research, using a statute and conceptual approach. The collected legal materials are then analyzed qualitatively, then presented descriptively. The results showed that the dimension of mediation of the penalties achieved was not formal justice through the Criminal Justice sub-system regulated in formal legal regulations. From a juridical perspective, mediation of penalties in the dimensions of state law (ius constitutum) is actually not well known and still leaves controversy, among those who agree and disagree to be applied. The essential issue leads to the choice of a pattern of criminal dispute resolution, related to the domain of state superiority with the superiority of the local wisdom community. The practice of mediating penalties at the Manokwari Police Department in the last 3 years (2017, 2018 and 2019) the number of criminal cases every year has always increased in number, as well as the mediation of cases conducted by the Manokwari Police Department each year experiencing an increase in the number of criminal cases being mediated.

Keywords: Penal Mediation, Prevention, Social Conflict.

Copyright @ 2020: This is an open-access article distributed under the terms of the Creative Commons Attribution license which permits unrestricted use, distribution, and reproduction in any medium for non-commercial use (NonCommercial, or CC-BY-NC) provided the original author and source are credited.

\section{INTRODUCTION}

The reality of some Indonesian people who still carry out customary institutions is a sociological factor in the institutional role of conflict resolution mechanisms. Based on Article 10 of Law No. 7 Year 2012 concerning Handling of Social Conflicts, customary institutions become one of the elements or institutional choices and mechanisms for resolving social conflicts. Article 41 specifically explains the adat mechanism as acting as a conflict resolution mechanism. Conflict resolution recommendations from adat mechanisms are recognized by the government. Giving the role of customary institutions in the Law on Social Conflict Management is a legal foundation for customary institutions in the conflict resolution system. However, there is still a need to study the position of adat institutions in the national legal system. In addition, see how the possibility of customary institutions can play a role in handling certain dimensions of conflict.

The diversity of Indonesia's ethnicity, religion, race and culture with a population of more than 259 [1] million is an indisputable sociological fact. Heterogeneous Indonesian people still partially recognize the existence of traditions or customs that originate from their cultural values. Direct or indirect social heterogeneity can contribute positively to efforts to improve people's welfare. On the other hand, social heteregonity also has a negative impact on national life if there are imbalances in development, injustice and social and economic inequality, as well as the uncontrolled dynamics of political life.

Democracy that provides openness to public space becomes an important variable in dynamizing Indonesia's heterogeneous society because openness encourages each interest group including indigenous groups to express and fight for interests. The struggle for interests can clash with other interests.

This dynamic condition places Indonesia as a country with a high level of vulnerability to social conflict. The conflict resulted in the loss of security, the emergence of community fear, environmental damage, loss of property, loss of life and psychological trauma such as revenge, hatred, and antipasti among social groups. The consequence of all of this is that public welfare is not realized. 
True law is formed and enforced as a means to provide protection to everyone in a just manner [2]. The philosophical formation of the Unitary State of the Republic of Indonesia is to realize the unity and integrity of the nation that overcomes all differences of opinion or conflicts that occur between community groups. As mandated in the 1945 Constitution of the Republic of Indonesia that the objective of the Unitary State of the Republic of Indonesia is to protect all Indonesians consisting of diverse ethnic, religious and cultural groups and to protect all of Indonesia's blood spills, including providing a guarantee of security and freedom from fear in order to realize public welfare.

Conflicts and/or clashes between community groups have the potential to create violent conflicts that result in disruption of national stability and impeded national development. The potential for conflict to become a form of violence among various social groups is influenced by the absence or low quality of the institutional conflict management available.

The customary pattern of dispute resolution in Indonesia fully belongs to the court [3]. Based on data from the Ministry of Home Affairs, the phenomenon of social conflict that occurs in Indonesia is increasing every year. Specifically in the jurisdiction of Manokwari Police Department, for the last 3 (three) years, namely 2017 to $2019,1,742$ criminal cases were handled by Manokwari Police Department. The case of social conflict is like an iceberg phenomenon, which only looks at the surface level. Though it is certain the number of actual cases must be far higher than that.

Tensions between groups or groups are also a cause of violence. Several cases of conflict with the SARA issue had broken out in Sampit, Ambon, Poso and several Papua Conflicts. Various horizontal conflicts actually have been managed by the mechanism of local wisdom. Local wisdom embodies the rules of customs that have lived for generations.

Heterogeneous Indonesian people still practice adat originating from local cultural values as a conflict management mechanism. Law No. 7 Year 2012 concerning Handling of Social Conflicts, has guaranteed and encouraged the function of customary institutions and/or social institutions in the management and resolution of social conflicts [4]. Activating the function of customary institutions in conflict management, so that conflicts find resolution and do not appear in the form of violence, is an effort to avoid overlapping conflict resolution mechanisms between adat mechanisms classified as ADR (alternative dispute resolution) with formal mechanisms such as the courts.

In the Criminal Law policy, the provision of crime to tackle crime is one of the efforts in addition to other efforts [5]. Mediation is an intermediary for taking an agreement between the perpetrator and the victim. The basis of this concept is taken from restorative justice which seeks to provide justice with a balance between victims and perpetrators [6].

From the perspective of the history of law at first there was no distinction between criminal law and civil law, so that every case would allow mediation [7]. Penal mediation is an alternative to settling criminal cases outside the criminal line. In the settlement of criminal cases if taking the criminal route it is usually always a criminal conviction by the judge against the perpetrator, this philosophically sometimes does not satisfy all parties, therefore it is necessary to think about the settlement of criminal cases through the ADR path with the intention that can resolve conflicts that occur between perpetrators and victims [8]. Penal Mediation is a legal breakthrough applied by law enforcement officials with reference to the Restorative Justice approach, considering that there is a goal to reconcile victims of crime with perpetrators of criminal acts through mediation in order to settle cases, return and repair damage and losses caused by a criminal case. This method can bring together the families of both parties, namely the families of victims and perpetrators, or by involving community leaders to find the best solution [9].

The existence of the mediation of penal is a new dimension examined from theoretical and practical aspects. As time goes by when an increase in the volume of cases is resolved in court, polarization and the mechanism of mediating justice are one of the solutions to reduce the volume of the case, as long as it is truly desired together with the parties (suspects and victims), and to achieve the interests broader, namely the maintenance of social harmonization [10]. Based on the aforementioned problems, this study seeks to examine how traditional and ideal adat institutions have a function as ADR mechanisms in handling social conflicts. This study will focus on which dimensions of social conflict are most relevant and cannot be handled by adat mechanisms. The purpose of this study is to analyze the penal mediation that does not aim to achieve formal justice and the practice of penal mediation at the Manokwari Police Department.

\section{RESEARCH METHODS}

This research is a normative legal research [11], which is equipped with empirical data, as well as legislation [12] and conceptual approaches [13]. The data used are secondary data in the form of primary legal materials (national legal instruments), and secondary legal materials (books, journals, research reports, and print and online media news) through literature studies. The collected legal materials are then analyzed qualitatively [14], then presented descriptively in order to answer the problems in this paper. 


\section{RESULTS AND DISCUSSION Penal Mediation is Not Aimed at Achieving Formal Justice}

The state is the main actor in the fulfillment of the rights of its citizens, including the fulfillment of a sense of security from crime and social conflict [15]. Montesquieu states that a good form of legislation should endorse crime prevention rather than punishment [16]. Formal criminal law cannot function without violations of norms of material criminal law (criminal acts) [17]. Settlement of cases outside the court through mediation of penalties is a new development in the realm of criminal law which has implications for the private dimension to be applied into the realm of public law. On the mediation dimension, this penalty is achieved not formal justice through the Criminal Justice sub-system regulated in formal legal regulations. From a philosophical perspective, the existence of the mediation of penal contains the principle of applying a "win-win" solution and not ending in a "lost-lose" situation as you wish achieved by the judiciary by achieving formal justice through a litigative legal process (law enforcement process). Through the mediation process, the highest justice is obtained because the agreement of the parties involved in the criminal case is between the perpetrator and the victim.

Rights are something that is inherent in every human being, and rights can be applied in every scope of life [18]. The victims and perpetrators are expected to find and reach the best solutions and alternatives to resolve the case. The implication of this achievement is that the perpetrators and victims can submit compensation offered, agreed upon and negotiated between them together so that the solutions achieved are "win-win". In addition, through mediation this penalty will have positive implications where philosophically the achievement of justice is carried out quickly, simply and at a low cost because the parties involved are relatively fewer than through the judicial process with components of the Criminal Justice System.

On the other side of the regulation making legislation as a partial legislative policy it turns out that the public nature of the Criminal Law is shifted in character because it relatively also enters the private realm by being known and practiced as a form of "Penal Mediation", although in the normative framework many are questioned but in in fact there are also criminal settlement practices outside the Criminal Justice System [19]. Penal mediation resolves criminal cases in a peaceful manner which can be said to be a concept that brings together victims and perpetrators of criminal offenses to discuss their interests and desires to resolve criminal cases that have occurred between them, and is assisted by a neutral mediator and helps resolve criminal cases involving those parties by providing legal advice as well as solutions in order to settle criminal cases as mediators [20].
In several countries, it is noted that customary justice institutions are still maintained as a means for communities to resolve disputes or problems they face, including criminal cases so that perpetrators, victims and the community and community leaders are felt to be more giving a sense of community justice. So as to encourage the re-establishment of communication within the community and improve harmony in community relations damaged by the offenders [21]. Judging from the sociological perspective is oriented to the cultural roots of Indonesian society where the cultural value of the family, put forward the principle of consensus agreement to resolve a dispute in a social system. Strictly speaking, these aspects and dimensions are resolved through the local wisdom dimension of customary law. Through the history of law, it can be seen that the first law applicable and reflects the legal awareness of the people of Indonesia is local wisdom.

Judged from a juridical perspective, mediation of the penal in the dimension of state law (ius constitutum) is actually not yet well known and still leaves controversy, among those who agree and disagree to be applied. The essential issue leads to the choice of a pattern of criminal dispute resolution, related to the domain of state superiority with the superiority of the local wisdom community. In addition to the above dimensions, other implications of the actual existence of a mediating penalty can be said between "there" and "nothing". It is said so, on the one hand because mediation of the penalties in the provisions of the law is not known in the Criminal Justice System but in the level under the law is known only through the discretion of law enforcement and its partial nature.

Then, on the other hand it turns out that the practice of mediating penalties has been carried out by the Indonesian people and the settlement is carried out outside the court such as through the mechanism of adat institutions. There are a number of facts and arguments that are worth mentioning in this context why a study of the concept of mediation is assumed to have assumed the existence between "there" and "nothing".

Reviewing the regulation under a partial and limited nature of the law, the mediation of the law is regulated in the Head of the National Police Letter No. Pol: B/3022/XII/2009/ SDEOPS dated December 14, 2009 concerning Handling Cases through ADR and Head of the National Police Regulation Number 7 Year 2008 concerning Basic Guidelines for Strategy and Implementation of Community Policing in the Implementation of National Police Duties. Basically, the regulation regulates the handling of criminal cases through ADR with the nature of small material losses, agreed by the parties, carried out through the principle of consensus agreement, carried out must respect social/customary norms and meet the principles of 
justice and if achieved through ADR the perpetrators are no longer touched by actions another law.

In addition, in a research interview on January 12, 2020 in Manokwari Police Department with Juman Simanjuntak as Head of Manokwari Police Department Criminal Operational Affairs Guidance Affairs said that [22]:

The legal basis for implementing mediation, which is one of the ADR systems in Indonesia is:

1. Pancasila as the basic ideology of the Republic of Indonesia which has one of the principles of deliberation to reach consensus.

2. The 1945 Constitution is the constitution of the Indonesian state where the principle of deliberation to reach agreement on the articles in it.

3. Article 7 paragraph (1) letter $\mathrm{j}$ of Law Number 8 Year 1981 concerning Criminal Procedure Law, that the investigator because of his obligations has the authority to take other actions according to the law responsible.

4. Article 51 paragraph (7) of Law Number 21 Year 2001 concerning Special Autonomy for the Province of Papua that in order to release a criminal offense from a criminal charge according to the provisions of the applicable Criminal Law, a statement of approval is required to be carried out from the Chair of the District Court whose territory is obtained through the Head the Public Prosecutor's Office concerned with the place where the crime occurred.

5. Article 16 paragraph (1) letter L of Law Number 2 Year 2002 concerning the Indonesian National Police is an act of pre-investigation and investigation.

6. Article 18 of Law Number 2 Year 2002 concerning the National Police of the Republic of Indonesia, that in the public interest of the Republic of Indonesia's National Police Officials in carrying out their duties and authorities act according to their own judgment.
7. Circular of the Head of National Police Number 8 Year 2018 dated July 27, 2018 concerning the Application of Restorative Justice in the Settlement of Criminal Cases and Mechanisms for Running Restoratives.

Presidential Instruction No. 8 Year 2002 concerning the Provision of Legal Certainty Guarantees to Debtors who have completed their obligations or legal actions to debtors who have not completed their obligations based on the settlement of shareholder obligations. This Presidential Instruction is addressed to several Ministers/Heads of Government Institutions, including the Minister of Justice and Human Rights, the Attorney General of the Republic of Indonesia, the Head of the Indonesian Police and the Chair of the Indonesian Bank Restructuring Agency. In the first dictum number 4 Presidential Instruction No. 8 Year 2002 states that, "in terms of providing legal certainty as referred to in number 1 concerning the release of debtors from criminal aspects directly related to the Shareholder Obligation Settlement program, which is still in the stage of investigation, investigation and/or prosecution by law enforcement agencies, then at the same time it is also carried out with the process of stopping the handling of criminal aspects, the implementation of which is still carried out in accordance with the provisions of the applicable laws and regulations ".

\section{Penal Mediation Practice at Manokwari Police Department}

The practice of mediating penalties although normative is not regulated by the law (positive law), but the practice occurs in Indonesian society. The practice of mediating penalties as practiced by the Manokwari Police Department in the resolution of several criminal cases, in the results of a study conducted on January 12, 2020 at the Manokwari Police Department. Researchers conducted a study and analysis of the last 3 (three) years criminal case documents which were settled by mediating the penalties presented in the table below:

Table 1: Number of Criminal Cases and Criminal Case Mediation in 2017, 2018 and 2019

\begin{tabular}{|l|l|l|l|l|l|}
\hline \multicolumn{2}{|l|}{ Number of Cases } & \multicolumn{3}{l|}{ Mediation } \\
\hline $\mathbf{2 0 1 7}$ & $\mathbf{2 0 1 8}$ & $\mathbf{2 0 1 9}$ & $\mathbf{2 0 1 7}$ & $\mathbf{2 0 1 8}$ & $\mathbf{2 0 1 9}$ \\
\hline 572 & 569 & 601 & 111 & 116 & 131 \\
\hline
\end{tabular}

Source: Criminal Case Data at Manokwari Police Departmen in 2020

From Table-1 it can be seen that in the last 3 (three) years, namely in 2017, 2018 and 2019 the number of criminal cases every year has always increased in number, so with the mediation of cases conducted by the Manokwari Police Department every year there has been an increase in the number of criminal cases mediated.

In those three years, several criminal cases that were mediated by the Manokwari Police Department
Criminal Investigation Unit were cases of lasas, minor maltreatment, destruction of goods, beatings between tribes and even murder cases with revenge motives. In this case there was a background of retaliation by the perpetrator for the death of his parents in 2014 by the victim, who then did not have the opportunity to pay or settle adat claims before the adat mediation resulting in the murder. From this case, the victim and the perpetrator have agreed to make peace with the 
condition that the perpetrators pay adat demands to pay blood to the victim as evidenced by a peace oath.

Then, on the same date and informant the researcher asked about criminal cases that could be mediated by the Manokwari Police Department, Juman Simanjuntak stated that [22]:

Not all criminal acts can be mediated, Manokwari Police Department has criteria and analysis by the Intelligence Unit cases that can be mediated including:

1) Can cause the effects of extensive social conflict if not immediately addressed by law enforcement officials, especially Manokwari Police Department,

2) Involving the masses from ethnic groups or races, both migrants and native Papuans.

3) Severe damage including burning houses, looting and persecution of each group.

4) Cause prolonged grudges and increased tensions between disputing parties, both their own families, groups and between tribes.

5) Causing paralysis of traffic lanes and commercial activities that exist in the Manokwari Police Department Area.

Based on that, through the mediation process the highest peak of justice is obtained because the agreement of the parties involved in the criminal case is between the perpetrator and the victim. The victims and perpetrators are expected to find and reach the best solutions and alternatives to resolve the case. The implication of this achievement is that the perpetrators and victims can submit compensation offered, agreed upon and negotiated between them together so that the solutions achieved are "win-win".

When elaborated in more detail, the nature of penal mediation is developed based on the ideas and working principles as follows [23]:

1. Conflict Handling: The mediator's job is to make the parties forget the legal framework and encourage them to be involved in the communication process. This is based on the idea, that crime has caused interpersonal conflict. That conflict is what the mediation process is aiming for.

2. Process-oriented (Process Orientation; Prozessorientierung): Mediation is more oriented towards the quality of the process rather than the results, namely: making the perpetrators of crimes aware of their mistakes, the needs of conflict resolved, the peace of the victims from fear, and so on.

3. Informal Proceedings-Informal Process: Penal mediation is an informal process, not bureaucratic, avoiding strict legal procedures.

4. There is active and autonomous participation on the part (Active and Autonmous ParticipationParteiautonomie/Subject subject): The parties (perpetrators and victims) are not seen as objects of criminal legal procedures, but rather as subjects who have personal responsibility and ability to act. They are expected to act on their own free will.

Partially and limited in nature, the mediation of the law is regulated in the Head of the National Police Letter No. Pol: B/3022/XII/2009/SDEOPS dated December 14, 2009 concerning Case Handling through Alternative Dispute Resolution (ADR) as well as the Regulation of the Head of Indonesian National Police Number 7 Year 2008 Concerning Basic Guidelines for Strategy and Implementation of Community Policing in the Implementation of National Police Duties. In the Head of National Police Letter No. Pol: B/3022/XII/2009/ SDEOPS dated December 14, 2009, several steps for handling cases through ADR are determined, namely:

1. Strive for handling criminal cases that have small material losses, the solution can be directed through the concept of ADR.

2. Settlement of criminal cases using the ADR must be agreed by the parties that litigate, but if there is no agreement, then it is settled in accordance with legal procedures that apply in a professional and proportional manner.

3. Settlement of criminal cases using ADR must be based on consensus and must be known by the surrounding community by including the local RT/RW

4. Settlement of criminal cases using ADR must respect social/customary norms and meet the principles of justice.

5. Empowering members of Community Policing and playing FKPM in their respective regions to be able to identify criminal cases that have minor material losses and allow them to be resolved through the ADR concept.

6. For cases that have been resolved through the ADR concept so that they are no longer touched by other legal actions that are counter productive with the aim of Community Policing.

Then in Article 14 letter f Regulation of the Head of the Republic of Indonesia National Police Number 7 Year 2008 concerning Basic Guidelines for Strategy and Implementation of Community Policing in the Implementation of Polri Duties determined that the application of the Alternative Dispute Resolution Concept (a pattern of solving social problems through more effective alternative channels in the form of efforts to neutralize the problem other than through legal process or litigation), for example through peace efforts this matter was perfected with the issuance of the Circular of the National Police Number 8 of 2018 concerning handling Restorative justice and its procedures. 
Settings for the settlement of cases outside the court through mediation of the penalties as the above context are regulated partially, are limited and the gradation of the arrangements is regulated at a level below the law. However, within the limits of the regulation at the law level, for criminal cases the principle cannot be resolved outside the court, although in certain cases, it is possible to have a settlement of a criminal case outside the court but does not include the scope of the mediation of the penalty. These provisions can be mentioned as follows:

1) In the case of a criminal act carried out in the form of "violations which are only threatened with criminal fines". The provisions of Article 82 of the Criminal Code determine the authority/right to demand that the violation violate, if the defendant has paid the maximum penalty for the violation and the costs incurred if the prosecution has been committed. In principle, the norm of the provisions of Article 82 of the Criminal Code is known as "afkoop" or "payment of a peaceful fine" which is one of the reasons for the eradication of prosecution.

2) In the case of a crime committed by a child under the age of 8 (eight) years. According to the provisions of Article 5 of Law 3/1997 concerning Juvenile Court, the age limit for juvenile delinquents that can be submitted to the court is at least 8 (eight) years and has not reached 18 (eighteen) years. Specifically, for children under the age of 8 (eight) years, investigators may hand over the child back to the parents, guardians, or foster parents if deemed to be able to be fostered or submitted to the Ministry of Social Affairs if they cannot be fostered by parents/guardians/Foster parents.

3) In the event of a case of violation of Human Rights as stipulated in Article 1 paragraph 7, Article 76 paragraph 1, Article 89 paragraph 4 and Article 96 of Law 39/1999 concerning Human Rights which gives authority to the National Commission on Human Rights to mediate in human rights violation cases. This aspect is only partial in nature, because there is no provision explicitly stating that all cases of human rights violations can be mediated by the National Commission on Human Rights, because the provisions of article 89 paragraph (4) specify that the National Commission on Human Rights can also only give advice to the parties to resolve disputes through the court, or only giving recommendations to the government or the People's Representative Council to be followed up on. In addition, the provisions of Law 39/1999 do not explicitly state that due to mediation by the National Commission on Human Rights can eliminate prosecution or conviction, but based on Article 96 paragraph (3) it is only determined that, "the mediation decision is legally binding and applies as legal proof.
As in the results of an interview conducted on January 7, 2020 at the Manokwari District Court office with informant Rodesma Ariyanto as Public Relations of the Manokwari District Court stated that [24]:

1) There is no derivation from article 51 paragraph (7) of Law Number 21 Year 2001 concerning Papua province's special autonomy which regulates the standard mechanism and format if criminal cases are resolved through mediation, customary justice or the agreement of the parties in cases that cause social conflict.

2) In addition to the diversion case, until 2019 there has been no determination of cases that were resolved through mediation because there was no standard format and there were no requests from other Law Enforcement officials.

3) Cases that have been handled and not brought to trial are the domain of other law enforcers.

4) The need for consideration of local wisdom in the Papuan community in deciding or handling cases in Papua and West Papua because it will take precedence that does not cause social conflict.

5) Wide area, difficult terrain, lack of facilities and infrastructure, lack of personnel of all officers in Manokwari has an impact in every case handling.

Based on the results of the interview that the application of penal mediation in the resolution of certain criminal cases, especially in the regions of Papua and West Papua, it is necessary to look at several factors into consideration, specifically intended to prevent social conflict in the region.

Then earlier on January 6, 2020, researchers conducted an interview with Juman Simanjuntak at the Manokwari Police Department and the informant stated that [22]:

1) Many cases faced by Manokwari Police Department, especially criminal investigations, are resolved through mediation, especially those that have a wide impact on the community, for example:

a) The Minus Jowen Case in Prafi,

b) The case of the burning of Warnyeti village,

c) Cases of fighting between the Makassar tribes and the central highlands in Wosi Dalam,

d) The case of the death of Adolf Salabay in Maruni,

e) Cases of the death of Goliath Dowansiba and Melianus Dowansiba.

f) Case fights at Dandis in Oransbari,

g) The case of the burning of the house of Herman Ahoren family was attacked and there were still many cases that were resolved by family.

2) In handling all criminal cases handled by Manokwari Police Department not all through litigation because it must be seen in the case case, both the impact caused and the benefits of the case 
are continued according to the intelligence function study.

3) Criminal matters or disputes reported at the Manokwari Police Department are familial or mediated, so they will be recorded in B 19 in the Criminal Investigation Unit.

4) The need to understand the local wisdom of the people who have problems so as not to have a broad and counter-productive impact with the main tasks of the Police namely maintaining security and order

The same thing was conveyed by the Chief of Police Intelligence Unit at Manokwari Police Department, that [25]:

1) The handling of criminal cases in Mnaokwari Police Department does not necessarily pass through the Judiciary in the Manokwari District Court because it pays attention to the impacts arising from the handling of the case itself, most importantly maintaining security and order in accordance with the mandate of Law Number 2 Year 2002.

2) In determining Criminal proceeding, investigation and legal remedies pay attention to studies carried out by the Intelligence function by taking into account facts on the ground and the impacts caused through the products of Special Daily Reports, Special Information, Information Reports, Estimated Conditions (Kirka), Quick Estimates (Kirpat) Special Estimates (Kirsus).

3) Intelligence function has the task of providing a picture to the leadership and side units, especially investigations in handling cases that have an impact or have the potential to cause social conflict so that a valid and accountable decision will be obtained.

4) Conflicts in the community that were started because of Criminal, Civil, Traffic accident or accusations of black magic (suanggi) in the Arfak community.

5) Criminal Settlements that impact social conflicts can be carried out or supported by tribal leaders, community leaders, traditional leaders, women and religious leaders who have influence in the midst of the community other than the regional government through National Unity of Manokwari Regency.

Based on the results of the two interviews conducted at the Manokwari Police Department in line with Adrianus Meliala's thought which states that in the context of the Criminal Justice System especially in its sub-system, the use of ADR is more effectively developed by the Police than the Prosecutor's Office or the Court. In this connection, it is inevitable if the use of ADR in this perspective is more felt to be developed by the Police rather than the Prosecutor's Office or the Court, given the role of the Police as the initial gate of the criminal justice system. It can be expected that a case that has started by ADR, say so, will be more likely to be continued and ended by ADR as well rather than ADR raised in the middle (when the case is handled by the Prosecutor's Office) or the end of the judicial process (meaning the court is decided) [26].

In addition, the same view was also said by Jasat Kadarusman as Acting Secretary of the West Papua Provincial Council stating that [27]:

"Until 2019, there were no standard rules regarding the handling of cases and mechanisms for resolving criminal and civil cases that had been resolved either by customary mediation, the Police or other officials in accordance with the mandate of the Special Autonomy Laws of Papua and West Papua in the form of Perasi, Perdasus and Regulations Governor. There are no legal instruments, customary judicial instruments because of the many customs, customs that grow and develop in Papua and West Papua according to the 2000 census of 1,068 tribes inhabiting Papua and West Papua as mandated by the Special Autonomy Law. The completion of criminal cases that have an impact or have the potential to cause the impact of social conflict has been carried out by law enforcement officers in Manokwari especially Manokwari Police Department, so far it has been effective in reducing the turmoil caused by criminal cases involving families, tribes or between certain groups".

In his statement, Jasat Kadarusman expressed his appreciation for law enforcement officers who manage the potential for conflict and potential conflict so that it does not have a wide-ranging impact on the community which can cause fear and anxiety among citizens both migrants and native Papuans.

Conflict threatens the security of an individual and that of his/her family [28]. The Restorative Justice approach in conflict resolution is basically a new method for resolving disputes, especially in criminalconcept cases, but using traditional patterns whose values do not have the concept of local wisdom in each culture. Therefore, the application of the restorative justice approach in conflict resolution is actually the use of traditional patterns with conflict resolution values that exist in local cultural policies, focusing on meeting victims of justice, through the concepts of equality, partnership, reconciliation and participation [29].

Basically, the context of the settlement of cases outside the court through mediation of the ultimate penalty is expected to be able to suppress the accumulation of cases (congestion) in the court, especially at the Supreme Court level. Although there are restrictions on cassation requests through regulations based on the provisions of Article 45A of Law number 5 Year 2004 in conjunction with Law Number 3 Year 2009, there will be an accumulation of 
cases every year. Therefore, the settlement of the case through mediation of penalties can also suppress the accumulation of cases at the level of judex facti (District Court/High Court).

Based on that, mediation as an instrument of alternative dispute resolution has four advantages or strengths. First, mediating penalties will reduce the victim's feelings of revenge, be more flexible because they do not have to follow the procedures and processes as in the criminal justice system, and cost less, and the process is faster than the litigation process (the process of settling a case in court). Second, the burden of the criminal justice system due to the accumulation of cases and the process of resolution which takes no less or less can be reduced by the presence of mediation between the perpetrators and victims. Third, mediation provides an opportunity for the victim to meet with the perpetrator to discuss crimes that have harmed his life, express his concern and feelings and request for restitution. Fourth, mediation creates a harmonious relationship between the victim and the perpetrator. This condition is not found in conflict resolution through the criminal justice system. Apologizing the victim to the offender will reduce the guilt of the offender and create reconciliation between the two.

Acceptability of penal mediation as an alternative settlement of criminal cases outside the criminal justice mechanism or being part of the criminal justice mechanism in Indonesia has a pretty good prospect based on several considerations. One such consideration is the mediation of penalties as an alternative dispute resolution which has roots in the nation's culture, especially in the customary law of various regions in Indonesia including the adat of the Papuan people.

\section{CONCLUSION}

In the mediation, the penalties achieved are not formal justice through the formal Criminal Justice subsystem regulated in formal legal regulations. From a juridical perspective, mediation of penalties in the dimensions of state law (ius constitutum) is actually not well known and still leaves controversy, among those who agree and disagree to be applied. The essential issue leads to the choice of a pattern of criminal dispute resolution, related to the domain of state superiority with the superiority of the local wisdom community. In addition to the above dimensions, other implications of the actual existence of a mediating penalty can be said between "there" and "nothing". It is said so, on the one hand because mediation of the penalties in the provisions of the law is not known in the Criminal Justice System but in the level under the law is known only through the discretion of law enforcement and its partial nature.
The practice of mediating penalties at Manokwari Police Department in the last three years, namely in 2017, 2018 and 2019, the number of criminal cases every year has always increased, as well as the mediation of cases conducted by Manokwari Police Department every year experiencing an increase in the number of criminal cases mediated. Some criminal cases that were mediated by the Manokwari District Criminal Investigation Unit were laka then cases, minor maltreatment, destruction of goods, beatings between tribes and there were even murder cases with revenge motives.

\section{REFERENCES}

1. http://nasional.kompas.com/read/2011/09/19/1059 4911/Jumlah.Penduduk.Indonesia.259.Juta accessed on July 4, 2019

2. Surbakti, N. (2011). Mediasi Penal Sebagai Terobosan Alternatif Perlindungan Hak Korban Tindak Pidana. Jurnal Ilmu Hukum, 14(1), 90.

3. Prihatini, L. (2015). Perspektif mediasi penal dan penerapannya dalam perkara pidana. Pakuan law review, 1(1).

4. Article 41 of Law No. 7 Year 2012 concerning Handling of Social Conflicts

5. Abildanwa, T. (2016). Mediasi penal sebagai upaya dalam rangka pembaharuan hukum pidana di indonesia berbasis nilai-nilai keseimbangan. Jurnal Pembaharuan Hukum, 3(1), 138-148.

6. Baroroh, H. B. (2012). Mediasi Penal sebagai Alternatif Penyelesaian Kekerasan Dalam Rumah Tangga/KDRT (Penal Mediation as an Alternative to Settling Domestic Violence), IN RIGHT: Jurnal Agama dan Hak Azazi Manusia, 2(1):184

7. Yusriando, Y. (2016). Implementasi mediasi penal sebagai perwujudan nilainilai pancasila guna mendukung supremasi hukum dalam rangka pembangunan nasional. Jurnal Pembaharuan Hukum, 2(1), 23-45.

8. Lasmadi, S. (2011). Mediasi Penal Dalam Sistem Peradilan Pidana Indonesia. INOVATIF $\mid$ Jurnal Ilmu Hukum, 4(5).

9. Sudarsono, C. (2015). Pelaksanaan mediasi penal dalam penyelesaian tindak pidana penganiayaan. Unnes Law Journal, 4(1):21.

10. Mulyadi, L. (2013). Mediasi Penal Dalam Sistem Peradilan Pidana Indonesia: Pengkajian Asas, Norma, Teori Dan Praktik. Yustisia Jurnal Hukum, 2(1).

11. Soekanto, S., \& Mamudji, S. (2011). Penelitian Hukum Normatif (Normative Legal Research), Jakarta: Rajawali Pers, 14.

12. Bambang, S. (2012). Metodologi Penelitian Hukum (Legal Research Methodology), Jakarta: Rajawali Pers, 98-99.

13. Marzuki, P. M. (2010). Penelitian hukum. (Legal Research), Jakarta: Kencana Prenada Media Group, 96. 
14. Soejono, \& Abdurrahman. (2003). Metode Penelitian Hukum (Legal Research Method), Jakarta: Rineka Cipta, 26.

15. Birkah, L., \& Kadarudin. (2012). Pengantar Hukum Internasional Introduction to International Law), Makassar: Pustaka Pena Press, 39.

16. Muhadar, \& Audyna, M. M. (2016). Kriminologi: Suatu Pengantar (Criminology: An Introduction), Makassar: Pusat Kajian Media dan Sumber Belajar, LKPP Universitas Hasanuddin, 3.

17. Andi, S., \& Nur, A. (2016). Hukum Pidana (Criminal Law), Makassar: Pustaka Pena Press, 3.

18. Kadarudin, K. (2015). Legal Guarantees and Inconsistency of State Recognition to the Right of Religion/Belief in Indonesia. Hasanuddin Law Review, 1(1), 1-16.

19. Zulfa, E. A. (2010). Keadilan Restoratif dan Revitalisasi Lembaga Adat di Indonesia. Indonesian Journal of Criminology, 4199.

20. Tawang, D. A. D. (2018). Alternatif mediasi penal dalam sistem peradilan pidana di indonesia. Jurnal Hukum Adigama, 1(2).

21. Apong, H. (2004). Restoratif Justice. Jurnal Kriminologi Indonesia, 3(3):26
22. Interview with Juman Simanjuntak, 6 January 2020 at the Manokwari Police Department Office.

23. Arief, B. N. (2008). Mediasi penal: penyelesaian perkara di luar pengadilan. Program Magister Ilmu Hukum, Pascasarjana, Undip. 7-12.

24. Interview with Rodesma Aroyanto, 7 January 2020 at the Manokwari District Court Office

25. Interview with Muhadi, 6 January 2020 at the Manokwari Police Department Office.

26. Meliala, A. (2005). Penyelesaian Sengketa Alternatif: Posisi dan Potensinya di Indonesia. official Website of Adrianus Meliala.

27. Interview with Jasat Kadarusman, January 8, 2020 at the West Papua Regional Parliament Office.

28. Kadarudin, K. (2018). Portraits in indonesia: international refugees face uncertain future (a study of international refugee law). Veritas et Justitia, 4(1), 1-29.

29. Sukardi. (2016). Penanganan Konflik Sosial dengan Pendekatan Keadilan Restoratif (Handling Social Conflict with a Restorative Justice Approach). Jurnal Hukum \& Pembangunan, 46(1):70. 